\title{
Molecular Markers of Secondary Organic Aerosol in Mumbai, India
}

Pingqing Fu, $*^{\dagger}$, , Shankar G. Aggarwal, ${ }^{\S, \$}$ Jing Chen, ${ }^{\|, \perp}$ Jie Li, ${ }^{\dagger}$ Yele Sun, ${ }^{\dagger}$ Zifa Wang, ${ }^{\dagger}$ Huansheng Chen, Hong Liao, ${ }^{\dagger, \triangle}$ Aijun Ding, ${ }^{\#}$ G. S. Umarji, ${ }^{\nabla}$ R. S. Patil, ${ }^{\nabla}$ Qi Chen, ${ }^{8}$ and Kimitaka Kawamura

${ }^{\dagger}$ State Key Laboratory of Atmospheric Boundary Layer Physics and Atmospheric Chemistry, Institute of Atmospheric Physics, Chinese Academy of Sciences, Beijing 100029, China

${ }^{\ddagger}$ Institute of Low Temperature Science, Hokkaido University, Sapporo 060-0819, Japan

${ }^{\S}$ CSIR-National Physical Laboratory, New Delhi 110012, India

"SKLEG, Institute of Geochemistry, Chinese Academy of Sciences, Guiyang 550081, China

${ }^{\perp}$ Institute of Geographic Sciences and Natural Resources Research, Chinese Academy of Sciences, Beijing 100101, China

\#Institute for Climate and Global Change Research \& School of Atmospheric Sciences, Nanjing University, Nanjing, 210093, China

${ }^{\nabla}$ Centre for Environmental Science and Engineering, Indian Institute of Technology Bombay, Mumbai, 400076, India

${ }^{8}$ State Key Joint Laboratory of Environmental Simulation and Pollution Control, College of Environmental Sciences and Engineering, Peking University, Beijing 100871, China

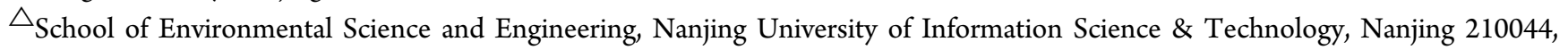
China

Supporting Information

ABSTRACT: Biogenic secondary organic aerosols (SOA) are generally considered to be more abundant in summer than in winter. Here, polar organic marker compounds in urban background aerosols from Mumbai were measured using gas chromatography-mass spectrometry. Surprisingly, we found that concentrations of biogenic SOA tracers at Mumbai were several times lower in summer (8-14 June 2006; wet season; $n=14)$ than in winter (13-18 February 2007; dry season; $n=10$ ). Although samples from less than $10 \%$ of the season are extrapolated to the full season, such seasonality may be explained by the predominance of the southwest summer monsoon, which brings clean marine air masses to Mumbai. While heavy rains are an important contributor to aerosol removal during the monsoon season, meteorological data (relative humidity and $T$ ) suggest no heavy rains occurred during our sampling period. However, in winter, high levels of SOA and their day/night differences suggest significant

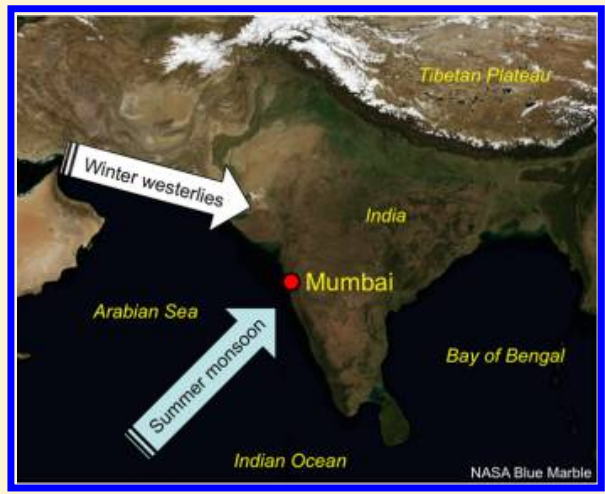
contributions of continental aerosols through long-range transport together with local sources. The winter/summer pattern of SOA loadings was further supported by results from chemical transport models (NAQPMS and GEOS-Chem). Furthermore, our study suggests that monoterpene- and sesquiterpene-derived secondary organic carbon (SOC) were more significant than those of isoprene- and toluene-SOC at Mumbai.

\section{INTRODUCTION}

Biogenic volatile organic compounds (BVOCs) released from terrestrial vegetation include isoprene, monoterpenes, sesquiterpenes, and oxygenated hydrocarbons (e.g., alcohols, aldehydes, and ketones). ${ }^{1,2}$ On a global scale, emissions of both biogenic terpenes and anthropogenic hydrocarbons are far lower than that of isoprene $\left(500-750 \mathrm{Tg} \mathrm{yr}^{-1}\right) .{ }^{1}$ Considerable efforts have been devoted recently to understand secondary organic aerosol (SOA) formation from the photooxidation of both anthropogenic and biogenic $\mathrm{VOCs}^{3-7}$ because SOA is one of the most important components in the atmosphere influencing the atmospheric radiation budget directly by scattering sunlight and indirectly by acting as cloud condensation nuclei. ${ }^{5}$ The global contribution of biogenic

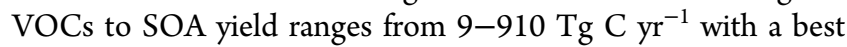

estimate of $60-240 \mathrm{Tg} \mathrm{C} \mathrm{yr}^{-1}$, which is 1 order of magnitude greater than that of anthropogenic VOCs. ${ }^{6}$ Changes in climatic conditions, chemical composition of the troposphere, and other environmental factors are expected to have a significant impact on BVOC emissions and SOA formation processes. ${ }^{8}$ For example, marine phytoplankton and seaweeds can also emit isoprene and other BVOCs; ${ }^{9,10}$ marine isoprene-derived SOA is important for understanding the aerosol-cloud-climate system over remote oceans. ${ }^{11}$

Received: January 25, 2016

Revised: $\quad$ March 27, 2016

Accepted: April 5, 2016

Published: April 5, 2016 
During the past decade, efforts have been made to characterize the molecular components of SOA from the photooxidation of BVOCs in continental aerosol samples, ${ }^{3,4,6,12-17}$ and also in aerosols from remote marine and polar regions. ${ }^{18-21}$ These studies provide insights into the sources and formation processes that influence SOA production and their spatial and temporal distributions. Several of these studies have focused on biogenic SOA in urban regions where anthropogenic activities can strongly influence the biogenic SOA formation. ${ }^{22}$ However, to date, very limited studies have been conducted into molecular marker compounds of SOA in tropical regions, ${ }^{3,13,23}$ especially in South Asia, ${ }^{24}$ which provides a unique environment with strong sunlight irradiation and high ambient temperatures to investigate the photochemical aging processes of atmospheric aerosols in this region.

To understand the levels of biogenic SOA and the different content of organic aerosols during different seasons in western India, we carried out a monitoring campaign in the megacity of Mumbai, one of the most populated (about 18 million) urban areas in the world. The Mumbai metropolitan region (ca. 4355 $\mathrm{km}^{2}$ ) lies on the coast of west India, facing the Arabian Sea. It has a tropical monsoon climate with diurnal land and sea breezes of daytime onshore and nighttime offshore winds, respectively. ${ }^{25}$ A recent modeling study has reported that the East Asian summer monsoon has a vital influence on aerosol concentrations in East China. ${ }^{26}$ Thus, Mumbai is an ideal site to investigate the influence of land/sea breezes and/or Indian monsoons on regional aerosol loadings and atmospheric chemistry. In this study, concentrations of molecular markers from the oxidation of isoprene, $\alpha / \beta$-pinene, $\beta$-caryophyllene, and toluene were investigated. We report contributions of each species to organic carbon (OC) and discuss the importance of biogenic and anthropogenic SOA tracers in Mumbai aerosols. The seasonality of SOA in western coastal India is also discussed using air mass back trajectory analysis and modeling results.

\section{MATERIALS AND METHODS}

Aerosol Sampling. We conducted sampling of atmospheric aerosols $\left(\mathrm{PM}_{10}\right.$, particles with an aerodynamic diameter $\leq 10$ $\mu \mathrm{m})$ on the rooftop (12 $\mathrm{m}$ a.g.l.) of a building at the campus of Indian Institute of Technology Bombay using a high-volume air sampler at a flow rate of $1.2 \mathrm{~m}^{3} \mathrm{~min}^{-1}$ with precombusted (450 ${ }^{\circ} \mathrm{C}$ for $\left.6 \mathrm{~h}\right)$ quartz fiber filters $(20 \times 25 \mathrm{~cm}$, Pallflex $)$. It is an urban background site at Mumbai $\left(19^{\circ} 05^{\prime} \mathrm{N}, 72^{\circ} 50^{\prime} \mathrm{E}\right)$, which is $10 \mathrm{~km}$ inland from the coast with little influence of transportation and industrial sources. Both daytime (06:0018:00, local time) and nighttime (18:00-06:00) aerosol samples were collected in early summer (8-14 June 2006; wet season; $n=14)$ and late winter (13-18 February 2007; dry season; $n=10$ ). It should be noted that the terms summer and winter in tropical India are different from their meaning in temperate regions. Because limited ambient aerosol samples were collected during both seasons, we performed the SOA modeling work using NAQPMS and GEOS-Chem to obtain month-averaged results of SOA loadings in this region. Detailed model description is provided in the Supporting Information (SI). After sampling, each filter sample was kept in a precombusted glass jar with a Teflon-lined screw cap, and stored at $-20{ }^{\circ} \mathrm{C}$ in darkness before analysis.

OC, EC, and WSOC Measurements. A small punch ( $\Phi 14$ $\mathrm{mm}$ ) of each sample was used for the measurements of organic carbon (OC) and elemental carbon (EC) by a Sunset Lab carbon analyzer, following the Interagency Monitoring of Protected Visual Environments (IMPROVE) thermal evolution protocol. ${ }^{27}$ Water-soluble OC (WSOC) was measured using a TOC analyzer (Shimadzu TOC-5000A).

Organic Species Analysis. A filter aliquot $\left(\mathrm{ca} .6 \mathrm{~cm}^{2}\right)$ of each sample was extracted three times with dichloromethane/ methanol $(2: 1 ; \mathrm{v} / \mathrm{v})$ under ultrasonication. Solvent extracts were filtered through a Pasteur pipet with quartz wool packed in it and concentrated by a rotary evaporator. They were further blown down to dryness under pure nitrogen gas. Then, the extracts were reacted with $50 \mu \mathrm{L}$ of N,O-bis(trimethylsilyl)trifluoroacetamide (BSTFA) with $1 \%$ trimethylsilyl chloride and $10 \mu \mathrm{L}$ of pyridine at $70{ }^{\circ} \mathrm{C}$ for $3 \mathrm{~h}$. The derivatives were diluted with $140 \mu \mathrm{L}$ of $n$-hexane containing $1.43 \mathrm{ng} \mu \mathrm{L}^{-1}$ of the internal standard ( $\mathrm{C}_{13} n$-alkane) before GC-MS injection. ${ }^{28}$

GC-MS Analysis. GC-MS measurements were performed on a Hewlett-Packard model 6890 GC coupled to a HewlettPackard model 5973 MSD. The gas spectrometer was equipped with a split/splitless injection and a fused silica capillary column (DB-5 ms, $30 \mathrm{~m} \times 0.25 \mathrm{~mm}$ i.d., $0.25 \mu \mathrm{m}$ film thickness). The mass spectrometer was operated in electron ionization (EI) mode at $70 \mathrm{eV}$. Target compounds were identified by comparison of mass spectra with those of authentic standards and literature data. ${ }^{3,14}$ Results of duplicate analysis showed that the relative standard deviation was generally $<10 \%$. All experiments were completed in March 2009. More detailed method descriptions are provided in the SI.

\section{RESULTS}

General Results. Detailed weather information has been described elsewhere. ${ }^{29}$ In brief, the weather at Mumbai is generally hot and humid in summer and hot and dry in winter. During the campaigns, ambient temperatures varied from 25.5-34.8 ${ }^{\circ} \mathrm{C}$ (mean $30.6{ }^{\circ} \mathrm{C}$ ) in summer and $20.5-33.7{ }^{\circ} \mathrm{C}$ $\left(25.3^{\circ} \mathrm{C}\right.$ ) in winter with clear diurnal variations (SI Figure S1). Relative humidity ranged from $50.2 \%$ to $98.0 \%$ (mean $77.4 \%$ ) in summer and from $27.0 \%$ to $43.0 \%$ (36.7\%) in winter during sampling periods.

Aerosol OC, WSOC, and EC concentrations are summarized in SI Table S1. OC levels were about three times higher in winter $\left(12-23 \mu \mathrm{g} \mathrm{m}^{-3}\right.$, mean $\left.\pm \mathrm{std}=15 \pm 3.3 \mu \mathrm{g} \mathrm{m}^{-3}\right)$ than those in summer $\left(3.3-6.1 \mu \mathrm{g} \mathrm{m}^{-3}, 4.5 \pm 0.91 \mu \mathrm{g} \mathrm{m}^{-3}\right)$. Similarly, higher EC and WSOC concentrations were found in winter. WSOC accounts for $22-45 \%$ (37\%) of OC in summer and $25-56 \%(39 \%)$ in winter. Thus, contributions of waterinsoluble organic carbon (WIOC) to OC were 55-78\% (63 \pm $5.7 \%)$ in summer, which were slightly higher than those (44$75 \%, 61 \pm 8.5 \%)$ in winter without significant differences.

Isoprene Oxidation Products. The previously reported isoprene oxidation products, that is, 2-methyltetrols (the sum of 2-methylthreitol and 2-methylerythritol), 2-methylglyceric acid (2-MGA), and $\mathrm{C}_{5}$-alkene triols were detected in the Mumbai aerosols. Their total concentrations were higher in winter (1.7$\left.9.9 \mathrm{ng} \mathrm{m}^{-3}, 4.1 \pm 2.4 \mathrm{ng} \mathrm{m}^{-3}\right)$ than in summer $(0.29-2.3 \mathrm{ng}$ $\left.\mathrm{m}^{-3}, 1.1 \pm 0.69 \mathrm{ng} \mathrm{m}^{-3}\right)$. The concentration ranges of 2methyltetrols were $0.14-1.4 \mathrm{ng} \mathrm{m}^{-3}\left(0.72 \pm 0.45 \mathrm{ng} \mathrm{m}^{-3}\right)$ in summer and $1.2-3.1 \mathrm{ng} \mathrm{m}^{-3}\left(2.0 \pm 0.59 \mathrm{ng} \mathrm{m}^{-3}\right)$ in winter. Concentrations of 2-methyltetrols at Mumbai were lower than those reported in urban aerosols in Chennai, Southeast India, where their levels were higher in summer $\left(3.5-43 \mathrm{ng} \mathrm{m}^{-3}, 9.1\right.$ $\left.\mathrm{ng} \mathrm{m}{ }^{-3}\right)$ than in winter $\left(0.17-11 \mathrm{ng} \mathrm{m}^{-3}, 2.8 \mathrm{ng} \mathrm{m}^{-3}\right){ }^{24}$ The total concentrations of isoprene SOA tracers at Mumbai were lower than in mountain aerosols such as those $(22-280 \mathrm{ng}$ 
$\mathrm{m}^{-3}$ ) from Mt. Changbai in northeast China ${ }^{14}$ and Mt. Fuji in Japan $\left(15-100 \mathrm{ng} \mathrm{m}^{-3}\right),{ }^{30}$ and at forested sites at Amazon ${ }^{3}$ and Europe. $^{31-33}$ 2-Methylerythritol was 2.4- to 2.5-fold more abundant than its isomer, 2-methylthreitol, which was consistent with those observed in other studies. ${ }^{3,17,31}$

Average concentrations of $\mathrm{C}_{5}$-alkene triols half those of 2 methyltetrols in winter, and are ten times lower than those of 2methyltetrols in summer (SI Table S1). Concentration ranges of 2-methylglyceric acid that is possibly formed by further oxidation of methacrolein and methacrylic acid from isoprene, ${ }^{34,35}$ were $0.10-0.83 \mathrm{ng} \mathrm{m}^{-3}\left(0.30 \pm 0.22 \mathrm{ng} \mathrm{m}^{-3}\right)$ in summer and $0.30-2.8 \mathrm{ng} \mathrm{m}^{-3}\left(1.2 \pm 0.80 \mathrm{ng} \mathrm{m}^{-3}\right)$ in winter.

$\boldsymbol{\alpha} / \boldsymbol{\beta}$-Pinene Oxidation Products. Eight organic acids were identified as $\alpha / \beta$-pinene oxidation products in the Mumbai aerosols, that is, 3-hydroxyglutaric acid, pinonic acid, pinic acid, 3-(2-hydroxyethyl)-2, 2-dimethylcyclobutane carboxylic acid, 3acetylglutaric acid, 3-acetyladipic acid, 3-isopropylglutaric acid, and 3-methyl-1, 2, 3-butanetricarboxylic acid (MBTCA).,6,16 Their total concentrations ranged from $11-72 \mathrm{ng} \mathrm{m}^{-3}(29 \pm$ $22 \mathrm{ng} \mathrm{m}^{-3}$ ) in winter, which were 2-3 times higher than those $\left(5.1-21 \mathrm{ng} \mathrm{m}^{-3}, 9.4 \pm 4.7 \mathrm{ng} \mathrm{m}^{-3}\right)$ in summer.

$\boldsymbol{\beta}$-Caryophyllene Oxidation Product. $\beta$-Caryophyllinic acid is formed through the ozonolysis or photo-oxidation of $\beta$ caryophyllene, a sesquiterpene known to have a high aerosol yield. ${ }^{36}$ Higher levels of $\beta$-caryophyllinic acid were also observed in winter than in summer.

Toluene Oxidation Product. 2,3-Dihydroxy-4-oxopentanoic acid (DHOPA) has been found to be a marker compound for toluene SOA. ${ }^{16}$ Its concentrations ranged from $0.06-1.9 \mathrm{ng}$ $\mathrm{m}^{-3}\left(0.62 \pm 0.55 \mathrm{ng} \mathrm{m}^{-3}\right)$ in winter, which were 1 order of magnitude higher than those $\left(0.008-0.21 \mathrm{ng} \mathrm{m}^{-3}, 0.05 \pm 0.055\right.$ $\mathrm{ng} \mathrm{\textrm {m } ^ { - 3 }}$ ) in summer.

Hydroxyacids. In the Mumbai aerosols, we detected hydroxyacids including glycolic acid, 3-hydroxybutyric acid, salicylic acid, 3-hydroxybenzoic acid, 4-hydroxybenzoic acid, and 3, 4-dihydroxybenzoic acid (SI Table S1). Concentrations of glycolic acid were much higher than those of 2-MGA, which were consistent with those reported in Canadian High Arctic aerosols where concentrations of glycolic acid ranged from $0.33-4.3 \mathrm{ng} \mathrm{m}^{-3}\left(2.0 \pm 1.3 \mathrm{ng} \mathrm{m}^{-3}\right) .{ }^{18}$

\section{DISCUSSION}

Air Masses Transport Characteristics. Three-day backward Lagrangian Particle Dispersion Modeling (Figure 1) was conducted by the Hybrid Single-Particle Lagrangian Integrated Trajectory (HYSPLIT) model. ${ }^{37}$ Such a method has shown good performance to simulate long-lived species (e.g., CO) and has been used to understand the origins and transport of air pollutants to the sampling site. ${ }^{38-40}$ The average distribution of retroplumes for each sample collected at Mumbai was calculated based on the backward particle release simulation for each hour during the sampling period. The retroplumes represent the distribution of probability or residence time of backward simulated air masses at $100 \mathrm{~m}$ altitude (a.g.l.). ${ }^{38,39}$ Figure 1 shows the results of retroplumes, which clearly indicate that air masses were mainly delivered from the Arabian Sea to Mumbai in summer when the summer monsoon prevails over the North Indian Ocean, ${ }^{41}$ bringing clean and humid marine air to the sampling site. In winter, dry air masses $(\mathrm{RH}=$ $27-43 \%)$ at Mumbai mainly originated from the northwestern continental regions across the Arabian Sea.

Diurnal/Seasonal Patterns. Weak diurnal trends of OC, EC and WSOC were observed in summer (SI Figure S2), while

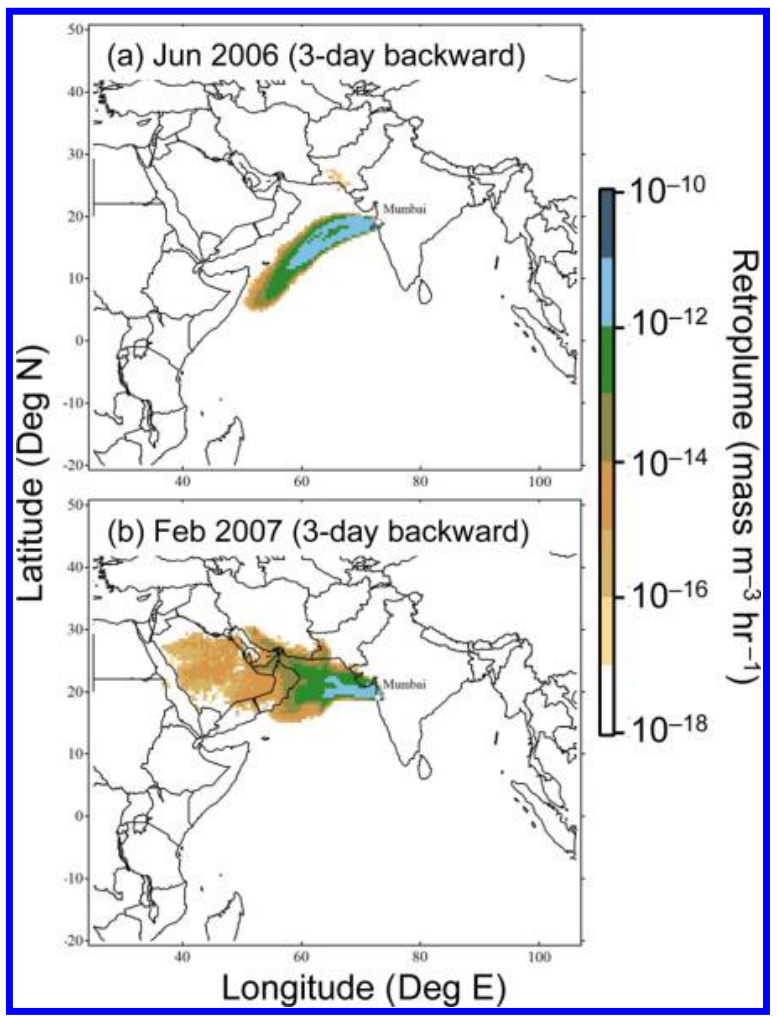

Figure 1. Averaged retroplumes ("footprint" residence time) showing the transport pathways (3-day backward) of air masses at Mumbai during each sampling periods.

relatively higher concentrations WSOC were observed in winter when air masses originated from the continental regions. Diurnal trends of most of the SOA tracers (Figure $2 a-d$ ) were characterized by higher concentrations in daytime than nighttime. Generally, atmospheric concentrations of organic aerosols in polluted continental regions are considered to be more significant than those in clean marine atmosphere. Higher concentrations of OC, EC, WSOC, and biogenic SOA tracers during the dry winter season demonstrate that wet removal may dominate organic aerosol loss during the summer monsoon season, ${ }^{29}$ although the diurnal trends of relative humidity and ambient temperature (SI Figure S1) suggest that no heavy rains occurred during the sampling period in summer. In addition, OC concentrations are expected to be higher at night when land breezes prevail. However, the higher daytime concentrations of biogenic SOA tracers, together with the weak diurnal trends of $\mathrm{OC}$ in both summer and winter, suggest a strong photooxidative production of these compounds from biogenic VOCs during the day. Rather, biogenic VOC emissions are generally considered to be, at least in part, leaf-temperaturedependent and other factors such as light, humidity and plant development and growth environment. ${ }^{42}$ The diurnal and seasonal variations of BVOCs including isoprene and monoterpenes should be one of the main factors controlling the atmospheric loading of biogenic SOA tracers at Mumbai, which warrants further studies. Nevertheless, compared with the effects of the summer monsoon and winter westerlies, the shifts of land/sea breezes during daytime/nighttime may play a minor role. Gas/particle partitioning may be another important factor affecting diurnal variations of biogenic SOA tracers and other organic species due to daytime/nighttime fluctuations of ambient temperatures (SI Figure S1). 


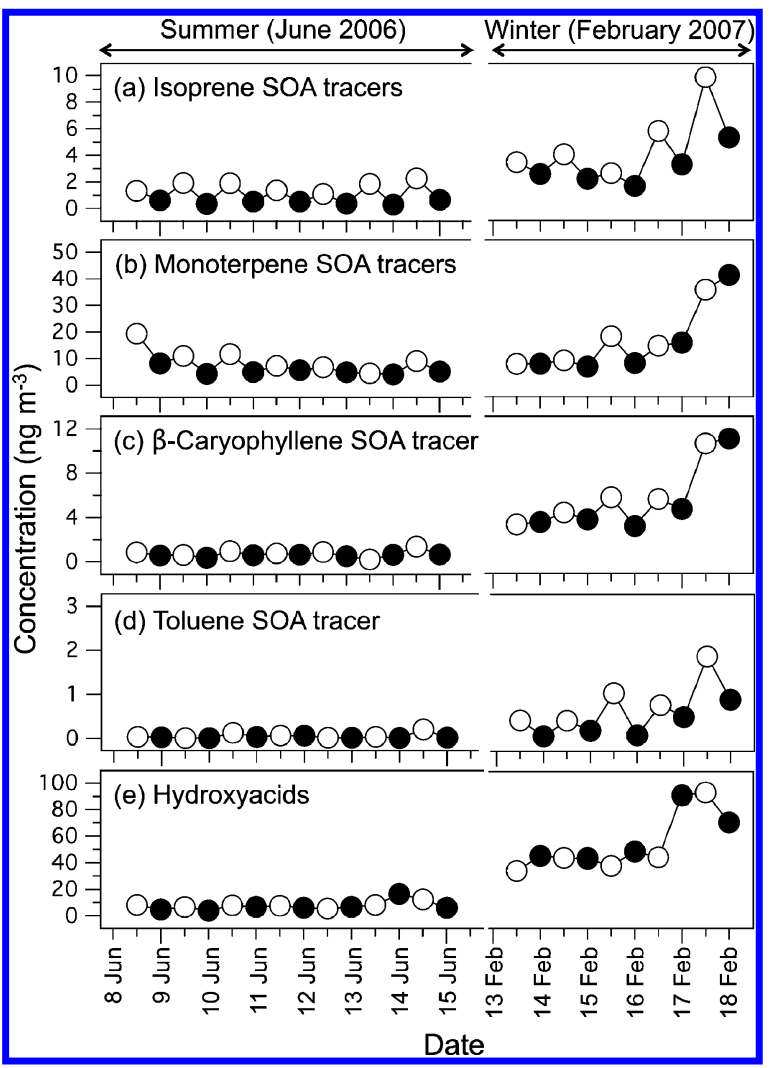

Figure 2. Diurnal variations of polar organic marker compounds measured in Mumbai aerosols collected during June 2006 and February 2007. The open and black circles represent daytime and nighttime samples, respectively.

The isoprene oxidation tracers, 2-MGA and $\mathrm{C}_{5}$-alkene triols, showed similar temporal trends to each other (Figure $3 a-b)$. In summer, 2-methyltetrols (Figure 3c) showed more obvious diurnal patterns than those of 2-MGA and $\mathrm{C}_{5}$-alkene triols. In winter, 2-MGA showed a stronger diurnal variation with daytime maxima. 2-Methyltetrols and $\mathrm{C}_{5}$-alkene triols are higher generation products formed from the photooxidation of epoxydiols of isoprene (IEPOX $=\beta$-IEPOX $+\alpha$-IEPOX) under low- $\mathrm{NO}_{x}\left(\mathrm{NO}_{x}=\mathrm{NO}+\mathrm{NO}_{2}\right)$ conditions. ${ }^{43}$ Concentrations of 2-methyltetrols were positively correlated $\left(R^{2}=0.65\right)$ with $\mathrm{C}_{5}$ alkene triols in the summertime samples. In winter, such a correlation was slightly weak $\left(R^{2}=0.44\right)$. 2-MGA is a $\mathrm{C}_{4^{-}}$ dihydroxycarboxylic acid that is formed via methacrylic acid epoxide (MAE) and has been identified as a key gas-phase intermediate resulting in isoprene-SOA formation from the high- $\mathrm{NO}_{x}$ pathway. ${ }^{44}$ 2-MGA was found to be less abundant than 2-methyltetrols. Interestingly, ratios of 2-MGA to 2methyltetrols presented no clear diurnal trends in summer, while they were much higher in daytime during the winter (Figure 3d). The winter air masses were transported from the northwest over neighboring suburban areas, with a greater chance of mixing with regional air masses influenced by anthropogenic emissions. ${ }^{29}$ Thus, our results again indicate that 2-MGA was enhanced in winter during long-range transport from continental regions where the atmospheric level of $\mathrm{NO}_{x}$ was high.

However, daytime/nighttime differences of hydroxyacids (Figure 2e and Figure S3) were minor in both summer and winter, especially for 3-hydroxybutyric acid and 3, 4dihydroxybenzoic acid. Glycolic acid is the smallest member

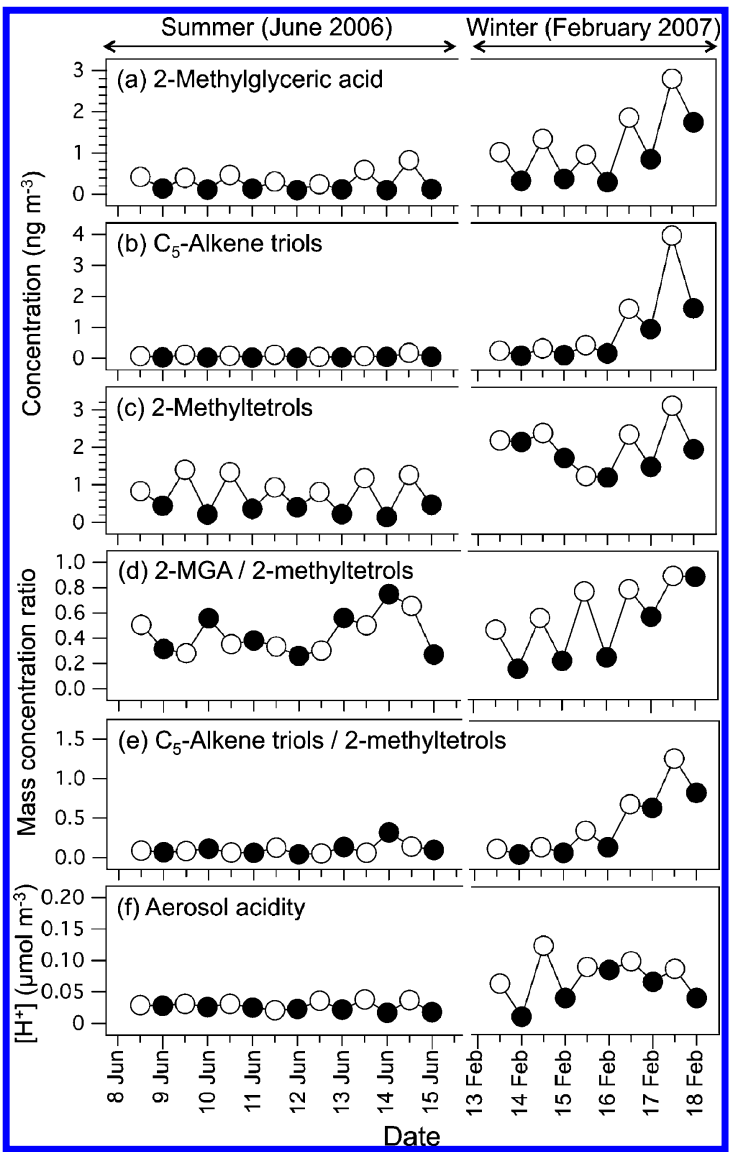

Figure 3. Diurnal variations of concentrations and mass concentration ratios of isoprene oxidation products, and aerosol acidity in the Mumbai aerosols.

of the family of $\alpha$-hydroxy acids, which is highly water-soluble and hygroscopic. Glycolic acid was the most abundant species $\left(1.2-5.4 \mathrm{ng} \mathrm{m}^{-3}, 2.8 \pm 1.2 \mathrm{ng} \mathrm{m}^{-3}\right)$ in the summertime aerosols, followed by 4-hydroxybenzoic acid. However, in winter, 4-hydroxybenzoic acid $\left(22 \pm 16 \mathrm{ng} \mathrm{m}^{-3}\right)$ was the dominant acid, followed by glycolic and 3, 4-dihydroxybenzoic acids. The levels of glycolic acid in winter $\left(16 \pm 10 \mathrm{ng} \mathrm{m}^{-3}\right)$ were much higher than those $\left(2.8 \pm 1.2 \mathrm{ng} \mathrm{m}^{-3}\right)$ in summer, indicating that glycolic acid may be mainly derived from terrestrial sources. However, a recent study found that levels of glycolic acid were strongly elevated in more biologically influenced marine aerosols over the North Pacific. ${ }^{45}$ Thus, the summertime dominance of glycolic acid may also suggest an increased input of marine microbial source to Mumbai via the summer monsoons.

Diurnal patterns of 3- and 4-hydroxybenzoic acids were characterized by higher concentrations in nighttime than daytime with the highest concentration observed on 13-14 June. Levoglucosan is a specific tracer of biomass burning, ${ }^{46}$ which also showed a concentration peak on 13-14 June. Its concentrations were higher in winter $\left(250-710 \mathrm{ng} \mathrm{m}^{-3}, 460 \pm\right.$ $\left.140 \mathrm{ng} \mathrm{m}^{-3}\right)$ than in summer $\left(29-200 \mathrm{ng} \mathrm{m}^{-3}, 69 \pm 46 \mathrm{ng}\right.$ $\mathrm{m}^{-3}$ ) (SI Figure $\mathrm{S} 3 \mathrm{~g}$ ), suggesting that biomass burning is a significant source of organic aerosols at Mumbai during nighttime, especially in winter. Moreover, the temporal trend of levoglucosan differed from that of 4-hydroxybenzoic acid. This can be explained, at least in part, by the fact that 4hydroxybenzoic acid is primarily produced by the burning of grasses and other nonwoody vegetation, while levoglucosan is a 
major pyrolysis product of cellulose and hemicellulose. ${ }^{46}$ Nevertheless, high concentrations of these organic species indicate that biomass burning is one of the major sources of organic aerosols at Mumbai. ${ }^{29}$

The temporal pattern of pinonic acid was different from those of pinic acid, 3-HGA and MBTCA (SI Figure S4). MBTCA and 3-HGA are higher-generation photooxidation products of $\alpha / \beta$-pinene compared to pinonic and pinic acids; ${ }^{47}$ atmospheric levels of 3-HGA were more abundant than MBTCA. Relatively low atmospheric concentrations of MBTCA may indicate that this acid can undergo photodegradation into low molecular weight (LMW) compounds under strong sunlight irradiation in tropical regions. In addition, concentrations of pinonic acid were much higher than pinic acid (SI Table S1), especially in summer, although pinonic acid has a vapor pressure of being 2 orders of magnitude higher than that of pinic acid. ${ }^{48}$ Higher levels of pinonic acid than pinic acid were also observed in summertime mountain aerosols at the summit of Mt. Tai, China, ${ }^{28}$ and other sites in Europe ${ }^{49}$ and North America. ${ }^{17}$ In the present study, pinonic acid was the only organic compound found to be more abundant in summer than in winter (SI Table S1). Ma et al. ${ }^{50}$ reported that the production of pinonic acid by ozonolysis of $\alpha$-pinene strongly depends on relative humidity, via two Criegee intermediates (CI1 and CI2). However, the formation of pinic acid only involves with one Criegee intermediate. In addition, different $\mathrm{NO}_{2}$ mixing ratios can significantly change the molar yields of pinic acid rather than pinonic acid; higher $\mathrm{NO}_{2}$ mixing ratios lead to a marked reduction of pinic acid and modest decrease of pinonic acid. ${ }^{51}$ These differences in reaction mechanisms may in part explain the enhanced concentrations of pinonic acid under high $\mathrm{RH}$ conditions in summer.

Total concentrations of SOA tracers were $5.8-24 \mathrm{ng} \mathrm{m}^{-3}$ (11 $\left.\pm 5.3 \mathrm{ng} \mathrm{m}^{-3}\right)$ in summer versus $17-89 \mathrm{ng} \mathrm{m}^{-3}(40 \pm 27 \mathrm{ng}$ $\mathrm{m}^{-3}$ ) in winter. Due to the strong influence of clean marine air, the summertime levels of biogenic SOA tracers at Mumbai were much lower than those $\left(18-110 \mathrm{ng} \mathrm{m}^{-3}\right)$ at Chennai, southeast India. ${ }^{24}$ Furthermore, the atmospheric levels of biogenic SOA tracers at Mumbai are much lower than those reported in forest sites at midlatitudes, ${ }^{14,28,31-33}$ and a subtropical urban site in Hong Kong ${ }^{13}$ (SI Table S3). This suggests that biogenic SOA tracers (e.g., 2-methyltetrols, MBTCA) may be further oxidized to lower molecular weight organic compounds such as oxalic acid ${ }^{52-55}$ under strong sunlight radiation and high RH in tropical regions, although emissions of biogenic VOCs at Mumbai and its surrounding regions are relatively low in comparison with other tropical regions. ${ }^{42}$ Oxalic acid has been proposed to be predominantly formed through aqueous/cloud chemistry from many compounds, including glyoxal, acetic acid, and glycolaldehyde. ${ }^{53-56}$

Contributions of BVOC Oxidation Products to OC. In order to better understand chemical compositions of SOA at Mumbai, relative contributions of isoprene, $\alpha / \beta$-pinene, $\beta$ caryophyllene and toluene oxidation products to OC were examined. Secondary organic carbon (SOC) concentrations derived from these VOCs were roughly estimated using a tracer-based method. ${ }^{16}$ Ambient concentrations of biogenic SOA tracers and laboratory-generated mass fractions $\left(f_{\text {soc }}\right)$ of marker compounds derived from given precursors into SOC concentrations were used to estimate the contributions to aerosol OC. The $f_{\text {soc }}$ factors for isoprene, $\alpha$-pinene, $\beta$ caryophyllene, and toluene are $0.155 \pm 0.039,0.231 \pm 0.111$, $0.0230 \pm 0.0046$, and $0.0079 \pm 0.0026$, respectively. ${ }^{16}$ Such an estimation may suffer from uncertainties under ambient conditions, a point being comprehensively discussed elsewhere. ${ }^{57-59}$

Figure 4 shows the temporal contributions of total SOC and their contributions to OC. In general, higher values of SOC

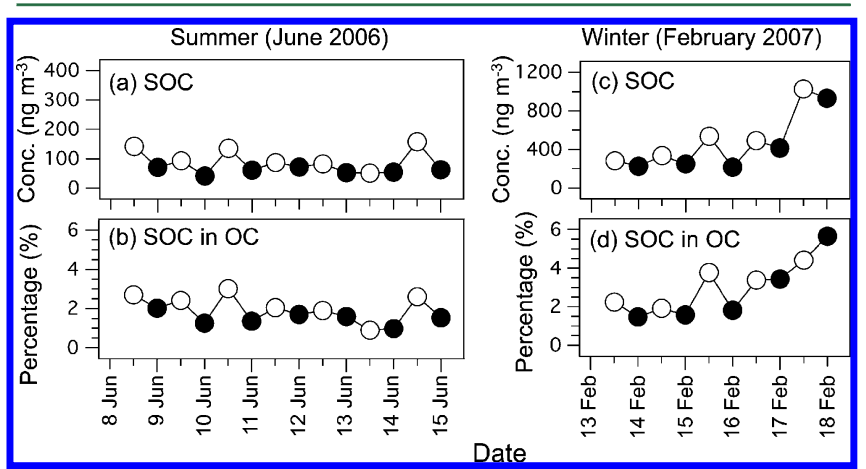

Figure 4. Temporal variations of (a) total concentrations of isoprene, $\alpha / \beta$-pinene, $\beta$-caryophyllene and toluene SOC that were estimated using a tracer-based method, ${ }^{16}$ and (b) the carbon percentage of biogenic SOC in organic carbon (OC) in the summertime Mumbai aerosols; (c) and (d) show the same for the winter.

were found during the daytime than those at night during both seasons. Mean concentrations of total SOC in summer (41$160 \mathrm{ngC} \mathrm{m}{ }^{-3}, 83 \pm 37 \mathrm{ng} \mathrm{m}^{-3}$ ) were only about one-sixth of those in winter $\left(216-1030 \mathrm{ngC} \mathrm{m}^{-3}, 470 \pm 290 \mathrm{ng} \mathrm{m}^{-3}\right)$ (SI Table S2). In summer, monoterpene SOC accounted for 0.43$1.8 \%(0.91 \pm 0.39 \%)$ of OC, making it the dominant contributor among the measured SOCs. Isoprene and toluene SOC contributed $0.14 \%$ and $0.13 \%$ to OC, respectively. In winter, sesquiterpene SOC was the dominant contributor, followed by monoterpene, toluene and isoprene SOC. In summer, the contributions of total SOC to OC $(0.86-3.0 \%, 1.9$ $\pm 0.66 \%)$ were lower than those in winter $(1.5-5.7 \%, 3.0 \pm$ $1.4 \%$ ). The majority (unidentified) organic species may include lipid compounds (e.g., $n$-alkanes and $n$-fatty acids), LMW dicarboxylic acids, phthalates, PAHs, organonitrates and organosulfates, amines and amino acids, polysaccharides, proteins, humic-like substances, and others. $6,22,24$

Aerosol acidity plays a significant role in SOA formation from the photo-oxidation of biogenic VOCs. ${ }^{60-62}$ Here the aerosol acidity was roughly estimated by the following equation: ${ }^{63,64}\left[\mathrm{H}^{+}\right]=2\left[\mathrm{SO}_{4}{ }^{2-}\right]+\left[\mathrm{NO}_{3}{ }^{-}\right]-\left[\mathrm{NH}_{4}{ }^{+}\right]$, where the brackets represent ion concentrations in molar units. ${ }^{29}$ The uncertainty of the estimation of aerosol $\mathrm{pH}$ by different proxies including the molecular ratio method, the ion balance method, thermodynamic equilibrium models (e.g., ISORROPIA-II and E-AIM), and the phase partitioning of ammonia can be found in Hennigan et al. ${ }^{65}\left[\mathrm{H}^{+}\right]$values ranged from $0.02-0.04 \mu \mathrm{mol}$ $\left.\mathrm{m}^{-3}(0.03 \mu \mathrm{mol} \mathrm{m})^{-3}\right)$ in summer, being lower than those $\left(0.01-0.12 \mu \mathrm{mol} \mathrm{m}{ }^{-3}, 0.07 \mu \mathrm{mol} \mathrm{m}^{-3}\right)$ in winter (Figure $3 \mathrm{f}$ ). The acidity of aerosol particles at Mumbai was close to those $\left(0.002-0.06 \mu \mathrm{mol} \mathrm{m}^{-3}\right)$ reported in marine aerosols collected during the MALINA campaign ${ }^{20}$ and was much lower than those in Chinese urban regions. ${ }^{66,67}$ Such a low level of aerosol acidity also contributes in part to the low SOA loading in tropical India.

In addition to the differences in formation processes of SOC and the emission strength of their precursors, the differences in the gas/particle partitioning of oxidation products from different VOCs may be a potential factor contributing to the 


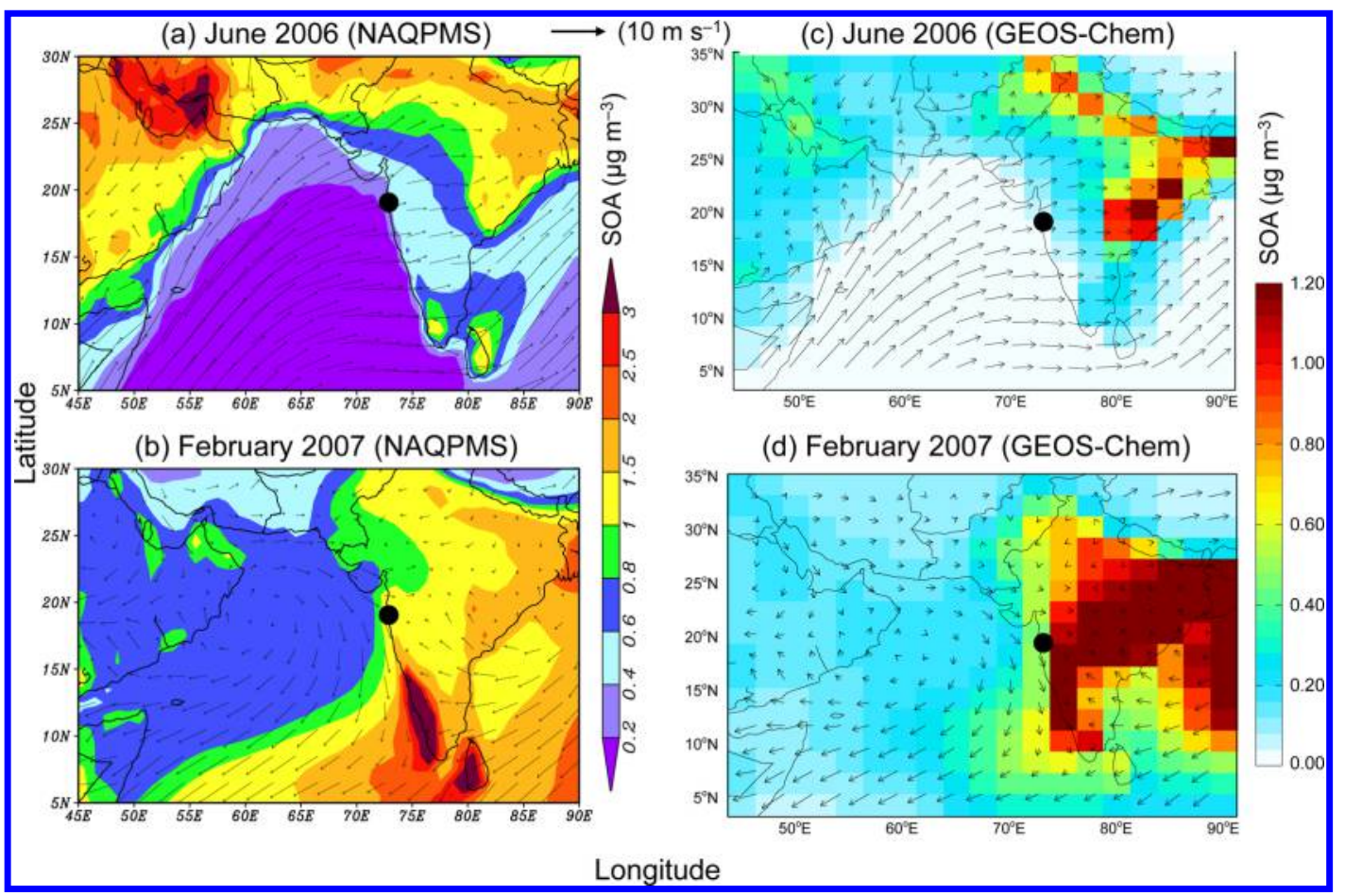

Figure 5. Spatial distributions of summed secondary organic aerosol (SOA) mass loadings $\left(\mu \mathrm{g} \mathrm{m}^{-3}\right)$ simulated by the NAQPMS model and GEOSChem model at ground level for June 2006 and February 2007, respectively. Arrows represent $10 \mathrm{~m}$ average wind speed. The location of Mumbai is marked as a black dot.

higher levels of monoterpene- and sesquiterpene-SOC than isoprene- and toluene-SOC in the Mumbai region. Indeed, the longer chain sesquiterpenes $\left(\mathrm{C}_{15} \mathrm{H}_{24}\right)$ and monoterpenes $\left(\mathrm{C}_{10} \mathrm{H}_{16}\right)$ have more carbon atoms than isoprene $\left(\mathrm{C}_{5} \mathrm{H}_{8}\right)$ and toluene $\left(\mathrm{C}_{7} \mathrm{H}_{8}\right)$, decreasing the vapor pressures of their oxidation products.

Regional SOA Burden Modeling. In order to support our observations of higher SOA loadings in winter than in summer, both the Nested Air Quality Prediction Modeling System (NAQPMS) ${ }^{68}$ and the GEOS-Chem model (v9-02, www. geos-chem.org) were used to estimate the regional distribution of SOA in South Asia. NAQPMS is a fully modularized 3-D chemical transport model derived from the Weather Research and Forecasting model. GEOS-Chem is a global chemical transport model that is driven by GEOS-5 assimilated meteorology. For NAQPMS, secondary organic aerosols are currently treated by a bulk two-product yield parametrization. ${ }^{69}$ For GEOS-Chem, biogenic and aromatic SOA formation is simulated by the gas-to-particle partitioning of SOA tracers formed from different precursors with $\mathrm{NO}_{x}$ dependent yields and a updated lumping scheme. ${ }^{70}$ More detailed model descriptions are provided in the SI.

Results from both models (Figure 5) clearly show that the spatial distribution of SOA was characterized by a gradual decrease from continental to marine regions in both June 2006 and February 2007. Although high phytoplankton activity in the surface ocean can emit a certain amount of isoprene and other BVOCs, their levels are rather minor compared to emissions from terrestrial plants. ${ }^{9,10,53}$ Here, the NAQPMS model results demonstrated that at Mumbai, SOA loadings were lower in June 2006 (about $0.6 \mu \mathrm{g} \mathrm{m}^{-3}$ ) than those in February 2007 (1.5 $\left.\mu \mathrm{g} \mathrm{m}^{-3}\right)$. The GEOS-Chem model results again showed that SOA loadings were much lower (about $0.072 \mu \mathrm{g} \mathrm{m}^{-3}$ ) in summer than those $\left(0.51 \mu \mathrm{g} \mathrm{m}^{-3}\right)$ in winter. These monthly averaged SOA burdens from both NAQPMS and GEOS-Chem are in agreement with field measurements that the prevailing wind currents of southwest monsoons and northeast monsoons strongly influence the Indian subcontinent in summer and winter, respectively. It should be noted that large discrepancies exist between the modeled SOA mass loadings and those derived from the tracer-based method (SI Table S2), which may result from differences in the species of VOCs that are included in each. In addition, some of the model biases have been attributed to missing SOA precursors in emission inventories, photochemical aging and aerosol water/cloud processing, or to the substantial effect of vapor wall loss on SOA yields in chamber studies. ${ }^{71}$

Similar to a previous study at Chennai, southeast India, ${ }^{24}$ concentrations of biogenic SOC and their contributions to aerosol OC at Mumbai were minor when compared with other locations around the world (SI Table S3). This may indicate that under conditions of strong sunlight irradiation and high ambient temperatures in South Asia, molecular compositions of organic aerosols at Mumbai differ from those in mid- or highlatitudinal regions. Furthermore, the SOA yield from cloudprocessing of isoprene oxidation products could be enhanced in regions where both $\mathrm{NO}_{x}$ levels and isoprene emissions are high $^{72}$ as SOA production from isoprene in the aqueous phase is influenced by initial $\mathrm{VOC} / \mathrm{NO}_{x}$ ratios and cloud contact time. $^{72}$ In addition, high ambient temperatures in tropical regions may affect SOA yields, gas/particle partitioning, and aging processes. Thus, the atmospheric composition of SOA at different geographical locations is highly complex, being regulated by many factors including local meteorological conditions, plant species, vegetation cover and regional chemistry, and therefore warrants further studies. In fact, both the quantification of SOA in ambient air and modeling of SOA remain a challenge due to the variety of the sources of 
VOCs and the complexity of SOA formation processes in the atmosphere in different environments. ${ }^{6}$ Nevertheless, our study strongly suggests that the Indian monsoon system plays a significant role in regional aerosol chemistry in west India.

\section{ASSOCIATED CONTENT}

\section{S Supporting Information}

The Supporting Information is available free of charge on the ACS Publications website at DOI: 10.1021/acs.est.6b00372.

The contents of the Supporting Information include detailed methods, three tables (Tables S1-S3), and four extensive figures (Figures S1-S4) (PDF)

\section{AUTHOR INFORMATION}

\section{Corresponding Author}

*Phone: +86-10-8201-3200; e-mail: fupingqing@mail.iap.ac.cn.

Notes

The authors declare no competing financial interest.

\section{ACKNOWLEDGMENTS}

This work was partly supported by the National Natural Science Foundation of China (41475117 and 41175106) and the Japanese Ministry of Education, Culture, Sports, Science, and Technology (MEXT) (19204055 and 24221001). P.F. appreciates financial supports from the Japan Society for the Promotion of Science (JSPS) and the "One Hundred Talents" program of Chinese Academy of Sciences.

\section{REFERENCES}

(1) Guenther, A.; Karl, T.; Harley, P.; Wiedinmyer, C.; Palmer, P. I.; Geron, C. Estimates of global terrestrial isoprene emissions using MEGAN (Model of Emissions of Gases and Aerosols from Nature). Atmos. Chem. Phys. 2006, 6, 3181-3210.

(2) Goldstein, A. H.; Galbally, I. E. Known and unexplored organic constituents in the Earth's atmosphere. Environ. Sci. Technol. 2007, 41 (5), 1514-1521.

(3) Claeys, M.; Graham, B.; Vas, G.; Wang, W.; Vermeylen, R.; Pashynska, V.; Cafmeyer, J.; Guyon, P.; Andreae, M. O.; Artaxo, P.; Maenhaut, W. Formation of secondary organic aerosols through photooxidation of isoprene. Science 2004, 303 (5661), 1173-1176.

(4) Kavouras, I. G.; Mihalopoulos, N.; Stephanou, E. G. Formation of atmospheric particles from organic acids produced by forests. Nature 1998, 395 (6703), 683-686.

(5) Kanakidou, M.; Seinfeld, J. H.; Pandis, S. N.; Barnes, I.; Dentener, F. J.; Facchini, M. C.; Van Dingenen, R.; Ervens, B.; Nenes, A.; Nielsen, C. J.; Swietlicki, E.; Putaud, J. P.; Balkanski, Y.; Fuzzi, S.; Horth, J.; Moortgat, G. K.; Winterhalter, R.; Myhre, C. E. L.; Tsigaridis, K.; Vignati, E.; Stephanou, E. G.; Wilson, J. Organic aerosol and global climate modelling: a review. Atmos. Chem. Phys. 2005, 5, 1053-1123.

(6) Hallquist, M.; Wenger, J. C.; Baltensperger, U.; Rudich, Y.; Simpson, D.; Claeys, M.; Dommen, J.; Donahue, N. M.; George, C.; Goldstein, A. H.; Hamilton, J. F.; Herrmann, H.; Hoffmann, T.; Iinuma, Y.; Jang, M.; Jenkin, M.; Jimenez, J. L.; Kiendler-Scharr, A.; Maenhaut, W.; McFiggans, G.; Mentel, T. F.; Monod, A.; Prévôt, A. S. H.; Seinfeld, J. H.; Surratt, J. D.; Szmigielski, R.; Wildt, J. The formation, properties and impact of secondary organic aerosol: current and emerging issues. Atmos. Chem. Phvs. 2009, 9, 5155-5235.

(7) Li, K.; Wang, W. G.; Ge, M. F.; Li, J. J.; Wang, D. Optical properties of secondary organic aerosols generated by photooxidation of aromatic hydrocarbons. Sci. Rep. 2014, 4, 4922.

(8) Fowler, D.; Pilegaard, K.; Sutton, M. A.; Ambus, P.; Raivonen, M.; Duyzer, J.; Simpson, D.; Fagerli, H.; Fuzzi, S.; Schjoerring, J. K.; Granier, C.; Neftel, A.; Isaksen, I. S. A.; Laj, P.; Maione, M.; Monks, P. S.; Burkhardt, J.; Daemmgen, U.; Neirynck, J.; Personne, E.; Wichink-
Kruit, R.; Butterbach-Bahl, K.; Flechard, C.; Tuovinen, J. P.; Coyle, M.; Gerosa, G.; Loubet, B.; Altimir, N.; Gruenhage, L.; Ammann, C.; Cieslik, S.; Paoletti, E.; Mikkelsen, T. N.; Ro-Poulsen, H.; Cellier, P.; Cape, J. N.; Horvath, L.; Loreto, F.; Niinemets, U.; Palmer, P. I.; Rinne, J.; Misztal, P.; Nemitz, E.; Nilsson, D.; Pryor, S.; Gallagher, M. W.; Vesala, T.; Skiba, U.; Brueggemann, N.; Zechmeister-Boltenstern, S.; Williams, J.; O’Dowd, C.; Facchini, M. C.; de Leeuw, G.; Flossman, A.; Chaumerliac, N.; Erisman, J. W. Atmospheric composition change: Ecosystems-Atmosphere interactions. Atmos. Environ. 2009, 43 (33), 5193-5267.

(9) Yokouchi, Y.; Li, H. J.; Machida, T.; Aoki, S.; Akimoto, H. Isoprene in the marine boundary layer (Southeast Asian Sea, eastern Indian Ocean, and Southern Ocean): Comparison with dimethyl sulfide and bromoform. L. Geophys. Res. [Atmos] 1999, 104 (D7), $8067-8076$.

(10) Shaw, S. L.; Gantt, B.; Meskhidze, N. Production and emissions of marine isoprene and monoterpenes: A review. Adv. Meteorol. 2010, 2010, DOI: $10.1155 / 2010 / 408696$.

(11) Meskhidze, N.; Nenes, A. Phytoplankton and cloudiness in the Southern Ocean. Science 2006, 314 (5804), 1419-1423.

(12) Kourtchev, I.; Ruuskanen, T.; Maenhaut, W.; Kulmala, M.; Claeys, M. Observation of 2-methyltetrols and related photo-oxidation products of isoprene in boreal forest aerosols from Hyytiälä, Finland. Atmos. Chem. Phys. 2005, 5, 2761-2770.

(13) Hu, D.; Bian, Q.; Li, T. W. Y.; Lau, A. K. H.; Yu, J. Z. Contributions of isoprene, monoterpenes, $\beta$-caryophyllene, and toluene to secondary organic aerosols in Hong Kong during the summer of 2006. L. Geophys. Res. 2008, 113, D22206.

(14) Wang, W.; Wu, M. H.; Li, L.; Zhang, T.; Liu, X. D.; Feng, J. L.; Li, H. J.; Wang, Y. J.; Sheng, G. Y.; Claeys, M.; Fu, J. M. Polar organic tracers in $\mathrm{PM}_{2.5}$ aerosols from forests in eastern China. Atmos. Chem. Phvs. 2008, 8, 7507-7518.

(15) Feng, J. L.; Guo, Z. G.; Zhang, T. R; Yao, X. H.; Chan, C. K.; Fang, M. Source and formation of secondary particulate matter in PM2.5 in Asian continental outflow. I. Geophvs. Res. [Atmos.] 2012, 117, D03302.

(16) Kleindienst, T. E.; Jaoui, M.; Lewandowski, M.; Offenberg, J. H.; Lewis, C. W.; Bhave, P. V.; Edney, E. O. Estimates of the contributions of biogenic and anthropogenic hydrocarbons to secondary organic aerosol at a southeastern US location. Atmos. Environ. 2007, 41, 82888300.

(17) Cahill, T. M.; Seaman, V. Y.; Charles, M. J.; Holzinger, R.; Goldstein, A. H. Secondary organic aerosols formed from oxidation of biogenic volatile organic compounds in the Sierra Nevada Mountains of California. I. Geophys. Res. 2006, 111, D16312.

(18) Fu, P. Q.; Kawamura, K.; Chen, J.; Barrie, L. A. Isoprene, monoterpene, and sesquiterpene oxidation products in the high Arctic aerosols during late winter to early summer. Environ. Sci. Technol. 2009, 43 (11), 4022-4028.

(19) Hu, Q.-H.; Xie, Z.-Q.; Wang, X.-M.; Kang, H.; He, Q.-F.; Zhang, P. F. Secondary organic aerosols over oceans via oxidation of isoprene and monoterpenes from Arctic to Antarctic. Sci. Rep. 2013, 3, 22802286.

(20) Fu, P. Q.; Kawamura, K.; Chen, J.; Charrière, B.; Sempéré, R. Organic molecular composition of marine aerosols over the Arctic Ocean in summer: contributions of primary emission and secondary aerosol formation. Biogeosciences 2013, 10 (2), 653-667.

(21) Ding, X.; Wang, X. M.; Xie, Z. Q.; Zhang, Z.; Sun, L. G. Impacts of Siberian biomass burning on organic aerosols over the North Pacific Ocean and the Arctic: Primary and secondary organic tracers. Environ. Sci. Technol. 2013, 47, 3149-3157.

(22) Nozière, B.; Kaberer, M.; Claeys, M.; Allan, J.; D’Anna, B.; Decesari, S.; Finessi, E.; Glasius, M.; Grgic, I.; Hamilton, J. F.; Hoffmann, T.; Iinuma, Y.; Jaoui, M.; Kahno, A.; Kampf, C. J.; Kourtchev, I.; Maenhaut, W.; Marsden, N.; Saarikoski, S.; SchnelleKreis, J.; Surratt, J. D.; Szidat, S.; Szmigielski, R.; Wisthaler, A. The Molecular Identification of Organic Compounds in the Atmosphere: State of the Art and Challenges. Chem. Rev. 2015, 115 (10), 39193983. 
(23) Stone, E. A.; Hedman, C. J.; Zhou, J.; Mieritz, M.; Schauer, J. J. Insights into the nature of secondary organic aerosol in Mexico City during the MILAGRO experiment 2006. Atmos. Environ. 2010, 44 (3), 312-319.

(24) Fu, P. Q.; Kawamura, K.; Pavuluri, C. M.; Swaminathan, T.; Chen, J. Molecular characterization of urban organic aerosol in tropical India: contributions of primary emissions and secondary photooxidation. Atmos. Chem. Phvs. 2010, 10 (6), 2663-2689.

(25) Venkataraman, C.; Reddy, C. K.; Josson, S.; Reddy, M. S. Aerosol size and chemical characteristics at Mumbai, India, during the INDOEX-IFP (1999). Atmos. Environ. 2002, 36, 1979-1991.

(26) Zhu, J. L.; Liao, H.; Li, J. P. Increases in aerosol concentrations over eastern China due to the decadal-scale weakening of the East Asian summer monsoon. Geophys. Res. Lett. 2012, 39, L09809.

(27) Wang, H. B.; Kawamura, K.; Shooter, D. Carbonaceous and ionic components in wintertime atmospheric aerosols from two New Zealand cities: Implications for solid fuel combustion. Atmos. Environ. 2005, 39 (32), 5865-5875.

(28) Fu, P. Q.; Kawamura, K.; Chen, J.; Li, J.; Sun, Y. L.; Liu, Y.; Tachibana, E.; Aggarwal, S. G.; Okuzawa, K.; Tanimoto, H.; Kanaya, Y.; Wang, Z. F. Diurnal variations of organic molecular tracers and stable carbon isotopic composition in atmospheric aerosols over Mt. Tai in the North China Plain: an influence of biomass burning. Atmos. Chem. Phvs. 2012, 12 (18), 8359-8375.

(29) Aggarwal, S. G.; Kawamura, K.; Umarji, G. S.; Tachibana, E.; Patil, R. S.; Gupta, P. K. Organic and inorganic markers and stable C-, $\mathrm{N}$-isotopic compositions of tropical coastal aerosols from megacity Mumbai: sources of organic aerosols and atmospheric processing. Atmos. Chem. Phys. 2013, 13, 4667-4680.

(30) Fu, P. Q.; Kawamura, K.; Chen, J.; Miyazaki, Y. Secondary production of organic aerosols from biogenic VOCs over Mt. Fuji, Japan. Environ. Sci. Technol. 2014, 48 (15), 8491-8497.

(31) Ion, A. C.; Vermeylen, R.; Kourtchev, I.; Cafmeyer, J.; Chi, X.; Gelencsér, A.; Maenhaut, W.; Claeys, M. Polar organic compounds in rural $\mathrm{PM}_{2.5}$ aerosols from K-puszta, Hungary, during a 2003 summer field campaign: Sources and diel variations. Atmos. Chem. Phvs. 2005, 5, 1805-1814.

(32) Kourtchev, I.; Ruuskanen, T. M.; Keronen, P.; Sogacheva, L.; Dal Maso, M.; Reissell, A.; Chi, X.; Vermeylen, R; Kulmala, M.; Maenhaut, W.; Claeys, M. Determination of isoprene and $\alpha-/ \beta$-pinene oxidation products in boreal forest aerosols from Hyytiälä, Finland: diel variations and possible link with particle formation events. Plant Biol. 2008, 10, 138-149.

(33) Kourtchev, I.; Warnke, J.; Maenhaut, W.; Hoffmann, T.; Claeys, M. Polar organic marker compounds in $\mathrm{PM}_{2.5}$ aerosol from a mixed forest site in western Germany. Chemosphere 2008, 73, 1308-1314.

(34) Claeys, M.; Wang, W.; Ion, A. C.; Kourtchev, I.; Gelencsér, A.; Maenhaut, W. Formation of secondary organic aerosols from isoprene and its gas-phase oxidation products through reaction with hydrogen peroxide. Atmos. Environ. 2004, 38, 4093-4098.

(35) Surratt, J. D.; Murphy, S. M.; Kroll, J. H.; Ng, N. L.; Hildebrandt, L.; Sorooshian, A.; Szmigielski, R.; Vermeylen, R.; Maenhaut, W.; Claeys, M.; Flagan, R. C.; Seinfeld, J. H. Chemical composition of secondary organic aerosol formed from the photooxidation of isoprene. I. Phys. Chem. A 2006, 110 (31), 9665-9690.

(36) Jaoui, M.; Lewandowski, M.; Kleindienst, T. E.; Offenberg, J. H.; Edney, E. O. $\beta$-Caryophyllinic acid: An atmospheric tracer for $\beta$ caryophyllene secondary organic aerosol. Geophvs. Res. Lett. 2007, 34, L05816.

(37) Draxler, R. R.; Hess, G. D. An overview of the HYSPLIT 4 modeling system for trajectories dispersion and deposition. Mateoro. Mag. 1998, 47, 295-308.

(38) Stohl, A.; Forster, C.; Eckhardt, S.; Spichtinger, N.; Huntrieser, H.; Heland, J.; Schlager, H.; Wilhelm, S.; Arnold, F.; Cooper, O. A backward modeling study of intercontinental pollution transport using aircraft measurements. I. Geophvs. Res. 2003, 108, 4370.

(39) Ding, A. J.; Wang, T.; Fu, C. B. Transport characteristics and origins of carbon monoxide and ozone in Hong Kong, South China. J. Geophys. Res. [Atmos] 2013, 118, 9475-9488.
(40) Ding, A. J.; Fu, C. B.; Yang, X. Q.; Sun, J. N.; Zheng, L. F.; Xie, Y. N.; Herrmann, E.; Nie, W.; Petäjä, T.; Kerminen, V.-M.; Kulmala, M. Ozone and fine particle in the western Yangtze River Delta: an overview of $1 \mathrm{yr}$ data at the SORPES station. Atmos. Chem. Phys. 2013, 13, 5813-5830.

(41) Cadet, D. Meteorology of the Indian summer monsoon. Nature 1979, 279, 761-767.

(42) Guenther, A.; Hewitt, C. N.; Erickson, D.; Fall, R.; Geron, C.; Graedel, T.; Harley, P.; Klinger, L.; Lerdau, M.; McKay, W. A.; Pierce, T.; Scholes, B.; S, R.; Tallamraju, R.; Taylor, J.; Zimmerman, P. A global model of natural volatile organic compound emissions. I. Geophys. Res. 1995, 100 (D5), 8873-8892.

(43) Surratt, J. D.; Chan, A. W. H.; Eddingsaas, N. C.; Chan, M. N.; Loza, C. L.; Kwan, A. J.; Hersey, S. P.; Flagan, R. C.; Wennberg, P. O.; Seinfeld, J. H. Reactive intermediates revealed in secondary organic aerosol formation from isoprene. Proc. Natl. Acad. Sci. U. S. A. 2010, 107 (15), 6640-6645.

(44) Lin, Y. H.; Zhang, H.; Pye, H. O. T.; Zhang, Z.; Marth, W. J.; Park, S.; Arashiro, M.; Cui, T.; Budisulistiorini, S. H.; Sexton, K. G.; Vizuete, W.; Xie, Y.; Luecken, D. J.; Piletic, I. R.; Edney, E. O.; Bartolotti, L. J.; Gold, A.; Surratt, J. D. Epoxide as a precursor to secondary organic aerosol formation from isoprene photooxidation in the present of nitrogen oxides. Proc. Natl. Acad. Sci. U. S. A. 2013, 110, $6718-6723$.

(45) Miyazaki, Y.; Sawano, M.; Kawamura, K. Low-molecular-weight hydroxyacids in marine atmospheric aerosol: evidence of a marine microbial origin. Biogeosciences 2014, 11, 4407-4414.

(46) Simoneit, B. R. T. Biomass burning-a review of organic tracers for smoke from incomplete combustion. Appl. Geochem. 2002, 17, $129-162$.

(47) Kourtchev, I.; Copolovici, L.; Claeys, M.; Maenhaut, W. Characterization of atmospheric aerosols at a forested site in Central Europe. Environ. Sci. Technol. 2009, 43 (13), 4665-4671.

(48) Bhat, S.; Fraser, M. P. Primary source attribution and analysis of $\alpha$-pinene photooxidation products in Duke Forest, North Carolina. Atmos. Environ. 2007, 41, 2958-2966.

(49) Kavouras, I. G.; Stephanou, E. G. Direct evidence of atmospheric secondary organic aerosol formation in forest atmosphere through heteromolecular nucleation. Environ. Sci. Technol. 2002, 36, 5083-5091.

(50) Ma, Y.; Willcox, T. R.; Russell, A. T.; Marston, G. Pinic and pinonic acid formation in the reaction of ozone with $\alpha$-pinene. Chem. Commun. 2007, 13, 1328-1330.

(51) Ma, Y.; Russell, A. T.; Marston, G. Mechanisms for the formation of secondary organic aerosol components from the gasphase ozonolysis of $\alpha$-pinene. Phys. Chem. Chem. Phys. 2008, 10, 4294-4312.

(52) Bikkina, S.; Kawamura, K.; Miyazaki, Y.; Fu, P. Q. High abundances of oxalic, azelaic, and glyoxylic acids and methylglyoxal in the open ocean with high biological activity: Implicationfor secondary OA formation from isoprene. Geophvs. Res. Lett. 2014, 41, 3649-3657.

(53) Myriokefalitakis, S.; Vignati, E.; Tsigaridis, K.; Papadimas, C.; Sciare, J.; Mihalopoulos, N.; Facchini, M. C.; Rinaldi, M.; Dentener, F. J.; Ceburnis, D.; Hatzianastasiou, N.; O’Dowd, C. D.; van Weele, M.; Kanakidou, M. Global modeling of the oceanic source of organic aerosols. Adv. Meteorol. 2010, 2010, DOI: 10.1155/2010/939171.

(54) Sorooshian, A.; Varutbangkul, V.; Brechtel, F. J.; Ervens, B.; Feingold, G.; Bahreini, R.; Murphy, S. M.; Holloway, J. S.; Atlas, E. L.; Buzorius, G.; Jonsson, H.; Flagan, R. C.; Seinfeld, J. H. Oxalic acid in clear and cloudy atmospheres: Analysis of data from International Consortium for Atmospheric Research on Transport and Transformation 2004. I. Geophys. Res., Atmos. 2006, 111 (D23).n/a10.1029/ 2005JD006880

(55) Liu, Y.; Monod, A.; Tritscher, T.; Praplan, A. P.; DeCarlo, P. F.; Temime-Roussel, B.; Quivet, E.; Marchand, N.; Dommen, J.; Baltensperger, U. Aqueous phase processing of secondary organic aerosol from isoprene photooxidation. Atmos. Chem. Phys. 2012, 12 (13), 5879-5895. 
(56) Carlton, A. G.; Turpin, B. J.; Altieri, K. E.; Seitzinger, S.; Reff, A.; Lim, H. J.; Ervens, B. Atmospheric oxalic acid and SOA production from glyoxal: Results of aqueous photooxidation experiments. Atmos. Environ. 2007, 41 (35), 7588-7602.

(57) Yttri, K. E.; Simpson, D.; Nojgaard, J. K.; Kristensen, K.; Genberg, J.; Stenström, K.; Swietlicki, E.; Hillamo, R.; Aurela, M.; Bauer, H.; Offenberg, J. H.; Jaoui, M.; Dye, C.; Eckhardt, S.; Burkhart, J. F.; Stohl, A.; Glasius, M. Source apportionment of the summer time carbonaceous aerosol at Nordic rural background sites. Atmos. Chem. Phvs. 2011, 11, 13339-13357.

(58) EI Haddad, I.; Marchewka, M.; Temime-Rousell, B.; Wortharn, H.; Piot, C.; Besombes, J.-L.; Baduel, C.; Voisin, D.; Armengaud, A.; Jaffrezo, J.-L. Insights into the secondary fraction of the organic aerosol in a Mediterranean urban area: Marseille. Atmos. Chem. Phvs. 2011, 11, 2059-2079.

(59) Shen, R. Q.; Ding, X.; He, Q. F.; Cong, Z. Y.; Yu, Q. Q.; Wang, $\mathrm{X}$. M. Seasonal variation of secondary organic aerosol tracers in Central Tibetan Plateau. Atmos. Chem. Phvs. 2015, 15 (15), 87818793.

(60) Surratt, J. D.; Lewandowski, M.; Offenberg, J. H.; Jaoui, M.; Kleindienst, T. E.; Edney, E. O.; Seinfeld, J. H. Effect of acidity on secondary organic aerosol formation from isoprene. Environ. Sci. Technol. 2007, 41 (15), 5363-5369.

(61) Offenberg, J. H.; Lewandowski, M.; Edney, E. O.; Kleindienst, T. E.; Jaoui, M. Influence of aerosol acidity on the formation of secondary organic aerosol from biogenic precursor hydrocarbons. Environ. Sci. Technol. 2009, 43 (20), 7742-7747.

(62) Rengarajan, R.; Sudheer, A. K.; Sarin, M. Aerosol acidity and secondary organic aerosol formation during wintertime over urban environment in western India. Atmos. Environ. 2011, 45, 1940-1945.

(63) Ziemba, L. D.; Fischer, E.; Griffin, R. J.; Talbot, R. W. Aerosol acidity in rural New England: Temporal trends and source region analysis. L. Geophys. Res. 2007, 112 (D10S22), doi:10.1029/ 2006JD007605.

(64) Zhang, Q.; Jimenez, J. L.; Worsnop, D. R.; Canagaratna, M. A case study of urban particle acidity and its influence on secondary organic aerosol. Environ. Sci. Technol. 2007, 41 (9), 3213-3219.

(65) Hennigan, C. J.; Izumi, J.; Sullivan, A. P.; Weber, R. J.; Nenes, A. A critical evaluation of proxy methods used to estimate the acidity of atmospheric particles. Atmos. Chem. Phvs. 2015, 15 (5), 2775-2790.

(66) He, K.; Zhao, Q.; Ma, Y.; Duan, F.; Yang, F.; Shi, Z.; Chen, G. Spatial and seasonal variability of PM2.5 acidity at two Chinese megacities: insights into the formation of secondary inorganic aerosols. Atmos. Chem. Phys. 2012, 12, 1377-1395.

(67) Ding, X.; Wang, X.-M.; Zheng, M. The influence of temperature and aerosol acidity on biogenic secondary organic aerosol tracers: Observations at a rural site in the central Pearl River Delta region, South China. Atmos. Environ. 2011, 45, 1303-1311.

(68) Wang, Z.; Maeda, T.; Hayashi, M.; Hsiao, L.-F.; Liu, K.-Y. A nested air quality prediction modeling system for urban and regional scales: application for high-ozone episode in Taiwan. Water, Air, Soil Pollut. 2001, 130, 391-396.

(69) Odum, J. R.; Jungkamp, T. P. W.; Griffin, R. J.; Flagan, R. C.; Seinfeld, J. H. The atmospheric aerosol-forming potential of whole gasoline vapor. Science 1997, 276, 96-99.

(70) Pye, H. O. T.; Chan, A. W. H.; Barkley, M. P.; Seinfeld, J. H. Global modeling of organic aerosol: the importance of reactive nitrogen $(\mathrm{NO}(\mathrm{x})$ and $\mathrm{NO}(3))$. Atmos. Chem. Phvs. 2010, 10 (22), $11261-11276$

(71) Zhang, X.; Cappa, C. D.; Jathar, S. H.; McVay, R. C.; Ensberg, J. J.; Kleeman, M. J.; Seinfeld, J. H. Influence of vapor wall loss in laboratory chambers on yields of secondary organic aerosol. Proc. Natl. Acad. Sci. U. S. A. 2014, 111 (16), 5802-5807.

(72) Ervens, B.; Carlton, A. G.; Turpin, B. J.; Altieri, K. E.; Kreidenweis, S. M.; Feingold, G. Secondary organic aerosol yields from cloud-processing of isoprene oxidation products. Geophvs. Res. Lett. 2008, 35 (2), doi:10.1029/2007GL031828. 